\title{
Kärlekens etos i Gösta Ågrens 1960-talslyrik
}

\section{Inledning}

"Kärleken är en syntes, en lugnande förklaring: allt må vara / förvirrat, men detta återstår alltid - livslagen" (Ågren 1959, 31). Så skriver den finlandssvenska diktaren Gösta Ågren i sin tredje samling Bergsväg (1959) och påståendet fungerar som ett slags nyckel till hans tidiga poesi. Hans syn på den erotiska kärleken som en livslag har inte mycket gemensamt med ett freudianskt libido. Till skillnad från psykoanalysens individualpsykologiska perspektiv är Ågrens kärleksbegrepp sammankopplat med övergripande kulturkritiska frågor och efterkrigstidens världspolitiska situation.

Ågren själv förhåller sig kritiskt till sin tidiga poesi och vill räkna sin egentliga debut från och med samlingen Molnsommar (1978) (Ågren 1990, 13). Michel Ekmans $(2000,150)$ åsikt i Finlands svenska litteraturhistoria är också att det dröjde länge innan Ågren blev en betydande författare och att det skedde först när han övergett politiken. I den omfattande utgåvan med Ågrens poesi Samlade dikter 1955-2015 (2016), har 1950- och 1960-talsproduktionen i stort sett uteslutits och endast några få omarbetade 1970-talsdikter medtagits. Följden av detta är bl.a. att den marxistiska utgångspunkten - som Michel Ekman likväl påminner om i sitt efterord (Ekman 2016, 536) - förbli tämligen osynlig i presentationen av hans lyriska livsverk. Detsamma gäller urvalssamlingarna Paus (1980) och En dal i våldet (1990), som enligt undertitlarna innehåller dikter från och med debuten 1955 men i själva verket hoppar över de första decenniernas produktion.

Något av det mest karakteristiska hos Ågren ligger i hans lyriska utforskningar av människan som tidlös gestalt, av människan som idé, vilket blir allt tydligare efterhand. Men helhetsbilden blir skev om man glömmer bort hans tidiga poesi, särskilt som den politiska dimensionen i så hög grad är integrerad med existentiella aspekter redan då. I en artikel har jag visat hur den vänsterpolitiska ideologin kommer fram i hans efterkrigstida poesi i växelspel med en romantisk idealism; och hur en lyriskt fruktbar spänning råder mellan dessa båda poler (Möller-Sibelius 2016). Syftet med min artikel här är av liknande slag, nämligen att undersöka hur en till synes tidlös kärlekstematik i Ågrens 1960-talsdiktning är sammankopplad med ett specifikt historiskt sammanhang och med ett underliggande politiskt engagemang. Ågren var vid denna tid medlem i Finlands kommunistiska parti och hade en marxistisk grundsyn utan att för den skull låta sig begränsas av ett partipolitiskt tänkande, hans engagemang utsträcker sig till ett mera allmänt etos (se von Bonsdorff 1983, 191-192). För att få grepp om vilket slags etos 
det är fråga om behövs en vidare idéhistorisk kontextualisering. I min analys kommer jag därför att knyta an till olika tänkare och traditioner såsom Theodor W. Adorno \& Max Horkheimer och deras kritik av västerländsk modernitet, den amerikanska essäisten och filosofen Ralph Waldo Emersons tankar om kärlek, Rudolf Steiners antroposofiska resonemang om människans inre utveckling samt Carl Gustav Jungs teori om människans individuationsprocess på det kollektivt omedvetnas nivå, närmare bestämt animagestalten som en aspekt i denna.

Ågren hör till de mest uppskattade bland samtida finlandssvenska poeter, han fick bl.a. Finlandia-priset 1988. Trots detta har inte mycket forskning gjorts om hans författarskap. Några artiklar och essäer har skrivits om paradoxen (Huldén 1986), långdikten (Madsen 2016) och författarskapet som en del av det finlandssvenska 1950-talet (Willner 1988). Två större bidrag är Åsa Stenwalls översiktliga kapitel om Ågren i hennes bok om rötter och rotlöshet hos några österbottniska författare, Den omöjliga hemkomsten (2006) och Carola Herberts publicerade avhandling pro gradu Någon annan tanke än dikten finns inte (2001), som undersöker det paradoxala i hans trilogi Jär (1988-1992) utgående från en existentialistisk tolkningsram. Med min egen forskning vill jag lyfta fram Ågrens bortglömda tidiga poesi, dess vänsterideologiska utgångspunkt och idéhistoriska sammanhang.

\section{Som en brinnande borg i ett invaderat land}

I Bergsväg formulerar Ågren de premisser som han sedan återkommer till i olika variationer, och som handlar om att kärleken måste hävda sin plats i en historiskt bestämd tid, mitt i en världspolitisk turbulens, om det vill sig så. I dikten "Födda -36” skriver han om sin egen generation som fått motta arvet av "blod, hunger / och en skräckfylld fred!" (Ågren 1959, 22), d.v.s. som finländare har deras barndom sammanfallit med vinter- och fortsättningskrigen, som européer har deras uppväxt präglats av andra världskrigets utbrott och dess efterverkningar. I den sista versgruppen, efter den mittersta versgruppens globala panorering med nedslag i enskilda personers lidande i Kenya, Sussex, Frankrike och Algerbergen, fokuseras diktjagets trotsiga uppmaning till sig själv och den älskade: "Blödande fram genom världen! / Kom min flicka! / Låt oss dansa till julis fioler. / Låt oss ana skillnaden mellan det som är / och det som borde vara. /... / Låt oss dansa bland alla svarta minnen. / Takten ger kanonernas symbaler!” (Ågren 1959, 23.) Uppmaningen riktas till de älskande själva men fungerar som ett allmänt credo, en tro på kärlekens möjligheter mellan två i en närmast apokalyptisk värld. Samma desperata yttre omständigheter råder i dikten "Hos dig” ur Säg farväl åt natten (1963): "Vår kärlek är som en brinnande borg / i ett invaderat land", heter det inledningsvis. Det är november (överlag en frekvent månad i Ågrens poesi) och diktjagets uppmaning är att "under fiendens fanborg älska, älska!" (Ågren 1963, 40). Den andra och sista versgruppen lyder: 
Väl inom dina ögons horisont

vill jag häftigt förändra

min dikt om år och människor

till sång om dessa två systrar,

vilka badat i min kärleks hav och blivit

outrannsakliga som tempelfönster,

djupa, glimmande - (Ågren 1963, 40.)

Kärleken innebär inte en frizon i den bemärkelsen att upplevelsen av ansvar för situationen utanför borgens väggar skulle upphöra ens temporärt. Men avgränsningen av perspektivet till den älskades blick väcker inte bara lust till objektet självt utan också till en fördjupad reflektion och en kreativ förnyelse. Jagets "dikt om år och människor", som han inspireras till att förändra och som ges feminina förtecken (de blir "systrar"), kan ses som en kamp att förhålla sig till mänsklighetens historia och dess destruktiva följdverkningar. I dem lever kärleksparet just nu. Men erfarenheterna har renats genom kärleken ("badat i min kärleks hav") och på ett revolutionerande sätt ("häftigt") kan detta transcendera diktandets premisser. Sången som dikten förvandlas till bär på ett mystiskt sätt - det sakrala bildspråket understyker detta - lösningen på ett större etiskt problem. I en annan dikt, "Styrkans födelse", ur samma samling framkommer denna aspekt ännu tydligare. Här citeras ett utdrag från början och slutet:

Som luft och sammet är du i min famn,

du, för vars skull jag mitt i striden

lämnar den och sjunker ned

och kysser tungt din hals,

[- - ]

och vi stiger

i rummets dunkel upp

med våta, ljusa kroppar

och vår styrka är en annan:

segerstyrka, vilande och ny. (Ågren 1963, 41.)

Att diktjaget genom sitt kärleksmöte tillfälligt lämnar sin uppgift i en odefinierad kamp framställs inte som ett svek. Tvärtom visar dikten (understruket även i titeln) att styrkan som behövs för utmaningarna i världen har sin källa i den erotiska kärleken. Denna styrka är av ett annat slag, paradoxal i sitt vilande väsen, och nedsjunkandet i den sinnliga njutningen leder till en stigande, transcendent men alltjämt fysisk upplevelse; adjektivet "våta" antyder det.

I senare dikter går utvecklingen för kärlekstematiken, och diktningen som helhet, i riktning mot större paradoxalitet (Huldén 1986, 128; Willner 1988, 214-215). I en titellös dikt ur Cellens dagrar (1970) utgör uteslutningen kärlekens oundvikliga motpol och förutsättning, tillsammans med andra existentiella belägenheter: "Varje seger har sitt nederlag, / varenda kärlek är en vägg mot dem man inte älskar / och ingen kan leva utan att dö” (Ågren 1970, 19). I den följande diktsamlingen Massmöte på jorden (1972) 
förhåller sig Ågren $(1972,11)$ hyperboliskt till frågan om erotik visavi solidaritet, och med en ironi han i allmänhet är sparsam med: "Redan svälter ingen människa i Kina. / Vi ligger i varandras öppnade kropp." Men t.ex. i dikten "Kärlek i november" ur Natten har djup för oss alla (1974) uttrycks igen tron på att kärleken inte är "stängd som en dörr": "Den är öppen som en väg / och jag vilar i ditt mjuka dis / en kväll i november, när jorden / är hunger och ropande händer" (Ågren 1974, 33).

I den estetiska idealismens tradition (som Ågren delvis anknyter till, se MöllerSibelius 2016) är sexualiteten mera problematisk. Enligt Holger Lillqvist (2001, 118) innebär sexualiteten i Edith Södergrans lyrik en katastrof som gestaltas med olika strategier ur den estetiska idealismen: "Aggressiv kantiansk dualism med sublim orientering förekommer sida vid sida med regressiva strategier med platonsk orientering." Mannens "glömska" anspelar hos Södergran på det som gått förlorat, men i övrigt tillerkänns inte den sinnliga kärleken någon roll "ens som den primitivaste avglansen av det ideala”. Nästan lika strängt förhåller sig Erik Johan Stagnelius, som i erotiken visserligen ser en blek avglans av det förlorade ideala men ingalunda någon ersättning för detsamma. (Lillqvist 2001, 204.) Lillqvist (2001, 209) konstaterar om Stagnelius och Södergran att det är som om dessa i bilderna av demoniserad sexualitet funnit det mest adekvata uttrycket för den sinnliga verklighet "som störtat det av 'absolut', översinnligt begär behärskade jaget i desillusion och närhet till döden."

I denna fråga står Ågren närmare den amerikanska transcendentalisten och livsfilosofen Ralph Waldo Emerson (som han går i dialog med i diktsamlingen Dikter utan land 2015). Denne formulerar en betydligt mera optimistisk syn i en essä om kärlek:

Den vidgar känslan; den gör den tölpaktige artig och ingiver den fege mod. Hos de mest beklagansvärda och förkastade ingjuter den mod att oförskräckt försvara världen; den bär ju nu det älskade föremålets drag. I det den skänker honom åt en annan, skänker den honom i än högre grad åt sig själv. Han är en ny människa, med nya förnimmelser, en ny och djärvare strävan, med en prägel av religiös värdighet över karaktär och livsmål. (Emerson 1922, 14.)

Dessa tankegångar om kärlekens förädlande kraft är besläktade med dem som finns i Ågrens dikter. Därmed inte sagt att just den sexuella aspekten skulle få något starkt understöd av Emerson (1922, 14): "Om emellertid själen allt för mycket sysselsätter sig med de materiella tingen och hemfaller till att söka grov kroppslig tillfredsställelse, så skördar den ingenting annat än lidande; ty kroppen blir ej i stånd att uppfylla det löfte, varmed skönheten lockar". Men den som förmår "utsläcka den låga lidelsen" blir ren och börjar uppskatta de andliga dygderna. Och när han lärt sig älska dessa i en enda människa lär han sig älska dem i alla, ”och så blir den ena sköna själen endast den dörr, genom vilken han inträder i alla sanna och rena själars samfund.” I Ågrens kärlekspoesi finns inget sådant förbehåll mot det kroppsliga och i det avseendet är han mera i samklang med sin samtids sexuella revolution än med 1800-talstänkaren. Men 
hans projekt handlar inte om att genom frispråkighet utmana konventioner och rasera tabun. I Cellens dagrar skriver han: "Sjuk går jag in i din sal av sammet. / Jag kunde tala direkt, om fittan, / men ordet är bittert som ett piskslag: / vi har länge hatat oss." (Ågren 1970, 32.) Samtidens sexualvokabulär är inte främmande för Ågren, den prövas här. Men för det som han vill ha sagt behövs ett annat språk.

\section{Rationalism och natur}

Motsättningen mellan rationalism och natur, transcendens och immanens, är något som ansetts prägla den västerländska kulturen. I Upplysningens dialektik diskuterar Max Horkheimer \& Theodor W. Adorno ur ett kulturkritiskt perspektiv den västerländska modernitetens framväxt som en rationaliseringsprocess. "Upplysningstänkandet", föreställningen om framåtskridande i denna vida bemärkelse, kan enligt deras mening hänföras ända till Homeros. Odyssén illustrerar människans strävan att tygla naturen utanför och inom sig, t.ex. Odysseus vilja att både lyssna till sirenernas sång och slippa undergången; genom att låta sig surras fast vid skeppets mast kan han både kontrollera sin drift och uppleva den sinnliga njutningen. (Horkheimer \& Adorno 1997, 75-76.) Enligt Horkheimer \& Adorno har priset för människans herravälde över naturen varit ett förnekande av naturen inom människan. Detta offer eller förnekande utgör kärnan i all civilisatorisk rationalitet men också fröet till en mytisk irrationalitet. Det egna livets ändamål blir förvirrat och oklart:

I samma stund som människan avskär sig från medvetandet om sig själv som natur blir alla de ändamål för vilka hon håller sig vid liv, samhälleligt framåtskridande, vidareutveckling av alla materiella och mentala krafter, ja själva medvetandet av intet värde; och denna intronisering av medlet som ändamål, som i senkapitalismen fått en karaktär av oförnekligt vansinne, kan urskiljas redan i subjektivitetens urhistoria. (Horkheimer \& Adorno 1997, 70-71.)

Ågren är inne på liknande spår i sin dikt "En tilldragelse vid Odysseus' hemkomst" ur Säg farväl àt natten. Den tar fasta på episoden ur Odysséns tjugoandra sång, där Telemakos, efter att friarna som invaderat Odysseus hem under hans frånvaro dödats, sköter om bestraffningen av de tolv tjänsteflickor som dessa haft sexuellt umgänge med. Telemakos tillspetsar faderns order om dödsstraff genom att välja en så föraktlig avrättningsform som möjligt, hängning. (Homeros 2008, 332-346.) Just denna ohyggliga passage diskuteras också av Horkheimer \& Adorno. De noterar att den kyligt bokförande beskrivningen av tjänsteflickornas dödsryckningar motsägs av det korta uppehåll som görs i texten efter kommatecknet - "Fötterna sprattlade till, några korta ögonblick bara." - (Homeros 2008, 345): "Genom att just här skapa en paus i berättelsen gör den det omöjligt att glömma de avrättade och ger en aning om det outsägliga eviga lidandet i den korta sekund som flickornas dödskamp varar." (Horkheimer \& 
Adorno 1997, 95-96.) Horkheimers \& Adornos uttalande har förståtts av Camilla Flodin $(2009,60)$ och andra uttolkare som att cesuren åstadkommer en självreflektion i berättelsen, det skapas en dissonans i eposets skenbart harmoniska enhet, vilket avslöjar berättelsen som en konstruktion. Lidandet som avrättningen innebär låter sig inte infogas i helheten som vilket moment som helst. Lidandet uttrycks genom cesuren och avslöjar att eposets ordning inte är naturgiven utan konstruerad.

Låt oss nu se på Ågrens dikt. Dikten är ganska lång och kan inte återges i sin helhet, men den tar avstamp i en grekisk urtid, någonstans mellan verklighet och saga, där Odysseus färd äger rum och "ett budskap" föds - och sviks:

$[--]$

kulturens första dröm, ren som Greklands klippor och havet.

Telemakos, son eller framtid, varför

höll över dagningens hjärta du ej,

bevarande, en fridfull sköld,

dina händer och ögon?

Nej.

Och på människans panna trycktes din blodade hand. Denna dag blev ett rop, som återskallar än: det judiska ropet, negerropet, ja, det sista, jungfruliga rop, som alla offer till avsked ger åt våra samma gudars offerpräster.

Din fader var härd för ett hat, som föddes ånyo i dig, härjande byggde av syndiga, varma tjänarinnor ett torn av ångest genom molnen och mot intet, med det sedan ständigt återfödda föraktet band deras glimmande halsar samman och utan nåd hejdade den röda vandringen i deras jungfruvener, modersåker för en drömlik framtid, värmen i vårt blod. Telemakos, din feberhandling lever än. Kärleken har ingen kunnat döda; striden, dock, har oavbrutet vidgats. I vågskålen har människan lagt allt: Homeros' myt och barnens myllrande väntan det allmänna giftet, stillheten i kaos.

Telemakos, ack, varför tog du på myternas dag inte i stället för döden till dig den skönaste kvinnan! (Ågren 1963, 23-24.) 
Inför lidandets och ondskans problem söker Ågren gärna lösningar på en mytisk, arketypisk nivå. Genom att etablera kontakt med en kollektiv djupdimension hos individen kan den goda, generella potential som finns hos mänskligheten mobiliseras (mera om detta senare). Men i denna rytmiskt manande dikt, som tar upp sitt motiv från den västerländska kulturens stora mytologiska epos Odysséen, verkar den utvägen bli omintetgjord. Vad finner man, när man går till "myternas skapelsetimme", som Ågren kallar det i diktens början? Jo, hat och hämnd och förgörelse hos dem som ska föreställa hjältar. Den som borde kunna fatta ett självständigt, djärvt och fritänkande beslut och utgöra en representant för den unga generationen, för den moderna kulturens och upplysningstänkandets framtid, Telemakos, sviker gruvligt. Diktens anaforiska och indignerade adressering av honom har att göra med att han personifierar en valmöjlighet som inte utnyttjas, en frihet som går förlorad. Han hänger sig åt irrationella hämndkänslor under täckmanteln av nödvändig rättskipning, moralisk rättfärdighet och sedlighetens försvar. Han offrar naturen i människan (sexualitetens berättigade kraft hos tjänarinnorna, liksom hos sig själv) till förmån för en förment rationalitet. Konsekvenserna är förödande, blir ett kulturellt prejudikat och ett slags prototyp för verklighetens förtryck genom historien - av folkslag, raser, kön (judarnas, de svartas, kvinnornas "rop").

Ågrens användning av beteckningen "jungfru" innebär ett insisterande på tjänarinnornas oskuldsfullhet, d.v.s. i deras "jungfruvener" består denna identitet orubbad, samlagen med friarna ändrar inte på detta, de har ingen skuld, den sinnliga kärleken är inget brott. Tvärtom, om Telemakos istället hade igenkänt och bejakat sin egen sexuella lust hade den homeriska berättelsen inte enbart varit mindre gruvlig, utan kunnat styra den västerländska kulturens utveckling åt ett mindre destruktivt håll. Vad gör vi när myterna beskriver människan så här? När de manliga hjältarna konstitueras av en självbehärskning, som för en idés skull accepterar hur mycket lidande som helst? Ska vi förtvivla, godta, resignera? Eller läsa kritiskt, notera cesurer, avslöja det förment nödvändigas godtycklighet, gå i dialog, skriva fram andra möjligheter? Ågrens dikt rör sig på ett metaplan där sådana frågor aktualiseras.

I dikten ”Din mun är mjuk...” ur Kungörelser (1965) adresseras kärleksobjektet i ett tilltal som bekräftar den älskades inre bestämmelse. Den förvirring och oklarhet gällande det egna livets ändamål som Horkheimer \& Adorno menade att hörde samman med upplysningstänkandets naturförnekelse råder inte här, men deras syn kan fungera som en förklarande bakgrund till varför något annat gäller istället:

Din mun är mjuk som ett nattligt ord, en långsam dyning.

Skymning skall komma, ett gråsidensläp in i ditt liv. 
Men Någon skall hålla på avlägsen ort en kammare varm.

Övergiv aldrig de bilder som uppstår omkring dig.

Låt någon annan förkasta fågelens glimmande lyftning.

Följ du ditt liv. (Ågren 1965, 37.)

Förutsättningen för att det egna livet i ett fundamentalt avseende ska upplevas vara i ordning tycks vara att "naturen" hos människan bejakas d.v.s. de aspekter som har med instinkt, intuition, myt, mystik och kropp att göra. Diktens anda, rytm och bildspråk har något elegiskt och heligt över sig och hela dikten är utformad som en öm och högstämd utsaga till den älskade. Man kunde säga att den förhåller sig oppositionellt till den avmystifiering som enligt Adorno \& Horkheimer präglar den västerländska modernitetens utveckling. Med avmystifiering menar de att all animism utrotas, att det mytologiska arvet avfärdas som vidskepelse och vanföreställningar, att människor lär sig avstå från mening och "ersätta begrepp med formel, orsak med regel och sannolikhet" (Horkheimer \& Adorno 1997, 19). Allt som inte fogar sig efter kalkylerbarhetens och användbarhetens krav uppfattas som något suspekt (Horkheimer \& Adorno 1997, 20). Att Ågren själv var medveten om mystiken som ett särskilt förhållningssätt visar bl.a. vissa aforistiska dikter, där han likväl underkänner den vanliga uppfattningen om vad mystik är och ger sitt paradoxala svar. I Bergsväg skriver han: "Mystikern försöker inbilla folk, att hans sinnen vet något om / evighetens djup. / Realisten försöker förklara hur underbart det är att förstå / problemets storlek.” (Ågren 1959, 33.) Och i Massmöte på jorden slår han fast: "Endast ateisten är mystiker. / Han understår sig inte att gripa in mot mörkret." (Ågren 1972, 17.) Ytterligare ett exempel kan ges ur Molnsommar: "/[- - ] Utan mystik / vill jag dö, avslutad, / sammanfattad, som när / i den grånande dagningen / mörkret förlossas” (Ågren 1978, 35). Dessa ställningstaganden hindrar honom inte från att själv utforska mystikens möjligheter i dikt och ge begreppet sin egen innebörd.

I sin doktorsavhandling om Dan Andersson, Kärlek som i allting bor (1971), citerar Ågren Hagar Olssons beskrivning av längtans roll i svensk dikt, ursprungligen publicerad i en essä 1942, som han finner träffa något väsentligt hos Andersson:

Det anses ju i allmänhet att det välordnade och socialt högtstående Sverige är ett land, där den materialistiska livsuppfattningen sitter i högsätet. Det är kanske riktigt, men i så fall är det bara en del av sanningen. Den andra delen av sanningen är den som svensk diktning och konst så oförtydbart uppenbarar: den dolda strömmen av innerlighet och längtan. Allt ifrån Birgittas och Swedenborgs dagar ända fram till de yttersta tidernas poeter går en ström av mysticism genom den svenska litteraturen. (Olsson citerad i Agren 1971, 15.) 
Till denna tradition av mystiker och "längtare" räknar hon även Dan Andersson, vars kända rader citeras: "Det är något bortom bergen, bortom blommorna och sången, / Det är något bakom stjärnor, bakom heta hjärtat mitt - " (ibid.). När Ågren - trots sina förbehåll gentemot mystiken, åtminstone i dess pretentiösa form - i sina dikter gestaltar en transcendent längtan gör han det alltså inom en svensk dikttradition som i hög grad bejakat ett mystiskt stråk, vid sidan av det materiella. Det är fråga om ett spänningsförhållande mellan dessa sfärer, vilket Ågren själv betonar i sin avhandling om Andersson. Detta präglar utan tvivel även hans egen poesi.

Något av samma önskan att förena det goda ur både vetenskap och religion som man finner hos Ågren utmärker Rudolf Steiner. Till det karaktäristiska för antroposofin hörde, alla vidlyftiga teorier till trots, någonting jordbundet och nyktert. "För Steiner själv var just det en hjärtefråga: ingen som inte kunde sy i sin egen byxknapp kunde, enligt ett av hans mest kända yttranden, bli en verklig filosof” skriver Jan Häll (2006, 88) i sin essäbok om Södergran och Steiner, Vägen till landet som icke är. Han förklarar vidare:

Detta "omätliga", "om vilket vi intet veta", är alltså en del av det som är, en bortskymd dimension av den sinnesbundna tillvaron. Steiners mystik är med andra ord immanent. Den syftar till en utvidgning av den värld vi redan känner, en förmälning av det osynliga med det synliga. [- - ] Sinnevärlden är inte avskild från den andliga världen, den springer fram ur den och kan bara genom den bli till fullo känd, precis som en människa måste förstås i förhållande till sin tankevärld och inte bara som kropp. (Häll 2006, 58.)

Om den vetenskapliga idealismen sökte idéerna, så söker antroposofin enligt Steiner det andliga livet i idéerna. En andlig formkraft bor i idéerna, precis som livet bor i organismen. I den mänskliga själen ligger imaginationen bakom tänkandet. (Steiner 1963, 32.) Den grekisk-romerska "varseblivningskulturen" föregicks av en äldre "uppenbarelsekultur" (utbredd bland egypter och kaldéer), som till sin karaktär var drömartat och inte logiskt men ändå djupt förbundet med andliga fakta i allt som lever och verkar. Människan betraktade tingen och allt talade till henne liksom en uppenbarelse och själslivets uttryck var bildartat. I och med den grekisk-romerska tidsåldern erkändes endast det som människan varseblev med sina sinnen. (Steiner 1963, 73-74.) Människan började bearbeta sina varseblivningar med hjälp av intellektet och genom förståndet få erfarenhet av sig själv som begrepp och idé. Tack vare den intellektuella kulturen kunde människan få jagkunskap och jagmedvetande. (Steiner 1963, 75.) Däremot har den andra andliga världen tett sig allt mer osäker medan förståndskulturen utvecklats och tagit över - därför vill antroposofin hålla kvar förståndskulturens fördelar men återerövra den andliga kunskap som gått förlorad sedan uppenbarelsekulturen försvunnit. (Steiner 1963, 79.) 
Förutsättningen för allt andligt kunskapssökande är en särskild grundstämning, det gäller att gå "vördnadens väg" (Steiner 1913, 6). Att utveckla den djupt rotade känslan att det finns något som är högre än vi själva är enligt Steiner svårt i "våra dagars förytligade civilisation” (början av 1900-talet, vill säga). Vår kritiska tidsålder värdesätter inte sådant som hängivenhet, vördnad, tillbedjan och beundran utan tränger undan dem. Den som söker "högre kunskap" måste alltså "frambringa dem inom sig" (Steiner 1913, 7, 10). "Vardagsmänniskan" bär inom sig en "högre människa", som kan skilja mellan det oväsentliga och det väsentliga, som inte bringas ur fattningen av alla möjliga tillfälligheter och yttre inflytanden utan präglas av lugn och säkerhet (Steiner 1913, 25-27). All strävan efter kunskap som går ut på att endast utöka sitt eget vetande leder bort från den rätta vägen; kunskap bör sökas i syfte att gagna mänsklighetens förädlande och världsutvecklingen (Steiner 1913, 19).

Man kan säga att dikten "Din mun är mjuk...” uppvisar ett liknande försök att få tag i ett annat slag av kunskap än den som kan nås enbart genom förstånd och varseblivning. Lyrismerna, den arketypiska metaforiken, den högstämda stilen, tilltalets ömma profetiskhet ger sammantagna ett intryck av andligt sökande, av en syftning bortom vardagsmänniskan i riktning mot en "högre människans" språk och gestaltning. Diktens rytm är lugn och rösten som talar manar den älskade att lita på sitt inre och inte låta sig påverkas av andra. Det är kring det adresserade duet som "bilder" genereras och dem måste hon hålla sig till, de är riktgivande. Huruvida andra, innefattande den omkringliggande kulturen, överhuvudtaget delar dessa inre bilder, detta perspektiv eller denna individuella andliga strävan spelar ingen roll. Till kvinnans egna viktiga bilder hör "fågelens glimmande lyftning" - lyrismen förstärks av den arkaiserande stavningen med den extra vokalen. Den är en transcendensbild, precis som "avlägsen ort" - och "kammare varm", som samtidigt är mjuk av assonanser och bevarar förbindelsen med en sensuell immanens. Ågren drar sig inte för att personifiera det transcendenta objektet, men han kallar inte detta "Gud" utan "Någon", vilket är ett steg bort från konfessionell terminologi och mot det osägbara.

Dialektiken mellan transcendens och immanens finns på flera plan i dikten. På den mest övergripande, tematiska nivån syns den som en förening av sensuell kärlek och andlig visdom. Dialektisk på motsvarande sätt är ordkonstruktionen "gråsidensläp", som sammanför lågt och högt: fattigdomens och askesen färg med ett exklusivt tyg och ett släp som för tankarna till en brudutstyrsel eller annan ytterst solenn klädedräkt. Kompositoriskt består dikten av två versgrupper med profetiska utsagor eller i alla fall betydelsemättade förutsägelser som förhåller sig antitetiskt till varandra ("Men") och två versgrupper av förmaningar. Sensmoralen tar alltså fasta på en inre självständighet, ett oberoende av andras val och handlingar, på möjligheten att finna sin egen väg. 


\section{Animagestalter och feminism}

Kvinnorna i Ågrens tidiga poesi är ofta ett mellanting mellan kärleksobjekt och ett slags anima-representationer. Carl Gustaf Jung menade att det finns sub-personligheter som existerar på ett omedvetet plan som arketyper i det kollektivt omedvetna. Mannens symboliska gestaltning av det motsatta könet kallade han anima och kvinnans motsvarande animus, utgående från det latinska ordet för själ. Dessa är alltså kontrasexuella arketyper i individens psyke. Den omedvetna feminiteten eller maskuliniteten är generellt dåligt utvecklade, men fungerar som vägledare till en djupare förståelse av den omedvetna världen och som en kopplerska/kopplare mellan individens jag och dennes inre liv. Beviset för denna förmedlande funktion fann Jung i sina patienters drömmar där anima/animus-gestalter ständigt förekom som följeslagare åt drömmaren, såsom ekon från sagor och kanoniserade verk, där gestalter av det motsatta könet leder hjälten eller hjältinnan till målet i slutet av berättelsen. (Hopcke 1991, 100-101.)

Den älskade skildras hos Ågren gärna i en hög stil. En titellös dikt ur Kungörelser lyder så här:

Tidigt på natten, tidigt i livet, sade hon: Min älskade, kom som en vinge över mig, ett blodmoln, förvildad!

Sent, på stigens tunna nerv över tunet, gick hon bort, hög som en lans, under höstens tatariskt glimmande sol, och hennes ögon var fåglar mot söder. (Ågren 1965, 60.)

Den sublima insceneringen och gestalten med de färrskådande ögonen för tankarna till någonting arketypiskt. Kvinnans uppmaning till sin älskade innehåller associationer till "vinge", "blodmoln" och något förvildat. Kärleksmötet verkar ha försett henne med dessa sublima krafter, eftersom hon kan gå stolt och stark som hon gör i den följande versgruppen. Tidigt har blivit sent, men tidsangivelserna bildar en harmonisk helhet, någonting fullbordat som på ett gåtfullt sätt öppnar upp mot framtiden och det främmande ("tatarisk" sol). Lansen och blodmetaforiken gör att kvinnan sammankopplas med strid och kamp. Trots Ågrens pacifistiska värdegrund använder han inte sällan ett krigiskt bildspråk för en uttrycka andliga ansträngningar och målsättningar, ungefär som när Paulus i brevet till efesierna uppmanar de kristna att ta på sig "hela Guds vapenrustning" i kampen som ska föras mot "ondskans andemakter" och inte mot "kött och blod" (Ef. 5:12-13). I den Södergran-alluderande dikten "Betraktelse över det förflutna och det aktuella” ur Säg farväl åt natten framställs den metaforiska kvinnogestalten tydligare i kontrast till våld och krig och hennes funktion som vägledare är uttalad: 
$[--]$

Igenom detta blodigaste sekel

har som en helig jungfru vandrat fram

landet som icke är, och endast hon

kan leda i inferno till en räddning:

insikt om landet, där människan är helig,

livets välvande djup, skrinet av kärlek,

vädjan och möjlighet, jordens morgon:

landet som icke är, men inom oss alltid skall vara

ett slutet öga, ett bidande frö. (Ågren 1963, 29.)

Här är kvinnan en liknelse för idén om "landet som icke är" och samtidigt en ledsagare lik Beatrice för pilgrimen Dante i Den gudomliga komedin. I Ågrens dikt gäller det inte enbart att fullfölja en individuell utvecklingsgång mot större psykologisk medvetenhet och integration, eller individuation, för att använda Jungs begrepp. Det vore reduktionistiskt att uppfatta dikten endast i individualpsykologiska termer när Ågren försöker gestalta en utväg för mänskligheten och en möjlighet till världens räddning. Därmed inte sagt att detta någonsin kan bli ett fullbordat faktum, men han lyfter fram idealismen som en nödvändighet, han ger inte upp tron på människans godhet som idé. I ett efterord till urvalssamlingen En dal i våldet skriver Ågren att bakom varje dröm och strävan finns de stora, eviga idéerna om "rättvisa och godhet, om jämlikhet och gemenskap, om frihet och sanning och kultur" (Ågren 1990, 165). Hans ställningstagande i dikten ovan sker i en efterkrigstida kontext och med en vänsterideologisk övertygelse i botten. Samhällsanknytningen bör vägas in, även om språket och stilen i dikten inte pekar åt det hållet. Lika litet som kärleksmötet i hans dikter är oberoende av världsskeendena är hans anima-gestalter frånkopplade 1900-talets stora etiska frågor. Dikten ovan ser inte ut som sextiotalets sociala engagemangslyrik, men bör betraktas som en del av den.

År 1977 utkom Ågrens historiska verk om Finland och finlandssvenskarna, Vår historia, skriven ur ett explicit marxistiskt perspektiv. Den stora lidelsefullheten i framställningen övertygar om att drivkraften för projektet ligger i en personlig upprördhet över allmänna sociala orättvisor och en djupt upplevd medkänsla för historiens förfördelade. Då och då kan han avbryta sin redogörelse, som innehåller mycket fakta och enskilda detaljer, med en övergripande och samtidigt känslomässig kommentar. En gång gäller kommentaren en av historiens drottningar:

För historieskrivaren, som frivilligt valt att i månader och år umgås med ett högadligt mördarfölje och rövarpack, som han inte skulle ägna tre rader om det kunde ignoreras utan men för det historiska sammanhanget - ja, för honom är en gestalt som Karin Månsdotter i urkunderna omstrålad av ett ljust skimmer. På historiens grymma, blodiga och förtvivlade sidor är hon lika oväntad som vacker, lika befriande som stor.

Här möter den första drottningen på Sverige-Finlands tron, som var värdig sin krona. Ingen hade hon dödat, ingen hade hon bestulit, ingen hade för hennes skull tvingats från gård och grund. Denna 17-åriga flicka av folket 
hade vuxit upp utan att det bröd, hon åt, tagits från hungrande barn, utan att de kläder, hon bar, betalats med skatteintäkter från utarbetade och utsugna medmänniskor.

Hennes liv innehöll arbete och kärlek.

Ett otroligt liv - för en drottning! (Ågren 1977, 46.)

Sättet att omtala Karin Månsdotter (1550-1612) liknar Ågrens sätt att skriva om lyriska kvinnogestalter, också hon blir närmast en anima-representation som får bära upp allt det ljusa som mänskligheten i övrigt verkar renons på. Hans positiva syn på just denna historiska regent sammanfaller med den allmänna uppfattningen om Karin Månsdotter (Larsson 2016), men därtill kommer den djuppsykologiska innebörd, den idealism och den historiematerialistiska medvetenhet som Ågren lägger in i sin tolkning av henne.

Åsa Stenwall $(2006,155)$ skriver att hon upplever Ågren som en "mycket 'manlig', ganska distanserad och ställvis rentav magistral diktare. Han tar motivistiskt ut svängarna, hans dikter gör anspråk på allmängiltighet. De påstår saker, förhåller sig, talar om mänskligheten och människan, historien och de stora linjerna." Han "vädjar till tanken mera än till kroppen" och "[v]ärlden tas in via huvudet" men samtidigt finns det bakom hans precisa bilder en "intellektuell högspändhet och andlig hetta". Jag tycker karakteriseringen är träffande, och till väsentliga delar stämmer den även för hans tidiga poesi, bortsett från att den unga Ågren utan tvekan tar in världen också via kropp och känsla. Intressant är det i varje fall vilken central roll han ger kvinnan både i sin historieskrivning och sin diktning, trots sin "manlighet" eller just på grund av den. Djuppsykologiskt sett kunde man säga att han vidkänns behovet av en feminin motvikt i sin individuationsprocess, och politiskt-etiskt erbjuder kvinnan/kvinnligheten som idé ett alternativ till ett patriarkalt och våldsamt samhällssystem, ett som istället bygger på fred, omsorg och kärlek.

Ågren framstår i sin 1960-talslyrik inte bara som en man som älskar kvinnor (till hans motiv hör utöver den älskade även den åldrande kvinnan, modern, systern) utan också som feminist i sin tilltro till det kvinnligas betydelse för en god samhällsutveckling. Könens särart är en avgörande tanke, lika självklar som könens jämbördighet. I en kommentar i Vasabladet den 5 september 1970 skriver han att Wava Stürmers feministiska diktbok Det är ett helvete att måla himlar, som utkommit samma år, är "skandalöst förbisedd". Han citerar några rader ur den: "Vi är lika många / Vi är lika starka / Vi är lika kloka", och kommenterar: "Världen är vansinnig: självklarheter förefaller djärva!".

\section{Sammanfattning}

Ågren är en tidig representant för marxistiskt tänkande inom finlandssvensk poesi. När frontalfiguren för finlandssvensk vänsterpoesi, Claes Andersson, får sitt genombrott med samlingen Sambället vi dör i (1967), har Ågren redan skrivit politisk dikt 
i över tio år. I många dikter är han explicit vänsterideologisk, vilket han inte är i den kärlekslyrik som jag exemplifierat ur här. Men min avsikt har varit att lyfta fram i vilken grad även en sådan "tidlös" tematik som kärlek mellan man och kvinna blir till social engagemangsdikt, som på ett odogmatiskt sätt hämtar näring ur en lång idéhistorisk tradition. 1970-talsdevisen att det privata är politiskt ger han tidigt sin egen innebörd genom att betona den erotiska kärlekens naturliga förbindelse med kulturens allmänna moralfrågor. Till skillnad från flera författare i den estetiska traditionen är kärleken också i sin sexuella aspekt en konstruktiv, inte en destruktiv kraft för Ågren. Den hör till en positivt upplevd natur, till ett område som den västerländska moderniteten förnekat i sin förnuftsorienterade idétradition, och måste därför försvaras och upprättas. Ågrens kärlekssyn är lika fysiskt bejakande som 1960-talets sexuella revolution men räknar dessutom med en andlig utvecklingsprocess som inte ingick i samtidens agenda kring sexuell frigörelse. Att världen står i brand medan mannen och kvinnan älskar är tragiskt, men hur viktig "kampen" än är (för det goda och rätta i samhället) måste kärleken ta sin plats. Den andliga kampen har i själva verket sin källa i denna sinnlighet, och idén om det goda ges kvinnlig gestalt. Hans kärlekslyrik är idealistisk och historiskt medveten; en marxists personliga svar och lyriskt modererade reaktion på världssituationen under 1960-talet.

\section{Litteratur}

Andersson, Claes 1967. Sambället vi dör i. Helsingfors: Schildts.

Bonsdorff, Monica von 1983. Eva Wichman och politiken. Helsingfors: Folkets bildningsförbund.

Ekman, Michel 2000. Poesin från trettiotal till femtiotal. Clas Zilliacus (utg.), Finlands svenska litteraturhistoria. Andra delen: 1900-talet. Uppslagsdel . Helsingfors: Svenska litteratursällskapet i Finland; Stockholm: Atlantis.

Ekman, Michel 2016. Frågornas diktare. Gösta Ågren, Samlade dikter 1955-2015. Helsingfors: Schildts \& Söderströms, 533-545.

Emerson, Ralph Waldo 1922. Kärlek och andra essayer. Översättning av August Carr. Berömda filosofer XXI, Stockholm: Björck \& Börjesson.

Flodin, Camilla 2009. Att uttrycka det undanträngda. Theodor W. Adorno om konst, natur och sanning [diss.]. Göteborg: Glänta produktion.

Herberts, Carola 2001. "Någon annan tanke än dikten finns inte i en dikt". Om det paradoxala i Gösta Ågrens trilogi Jär. Meddelanden från avdelningen för nordisk litteratur nr 11. Helsingfors: Nordica.

Homeros 2008. Odyssén. Tolkad och kommenterad av Ingvar Björkeson. Inledning av Sture Linnér. Stockholm: Natur och Kultur. 
Hopcke, Robert H. 1991. Jungs psykologi. En resa genom C. G. Jungs samlade verk. Översättning Sten Andersson, svensk fackgranskning Lars-Göran Eriksson. Stockholm: Natur och Kultur.

Horkheimer, Max \& Theodor W. Adorno 1997. Upplysningens dialektik. Filosofiska fragment. Översättning Lars Bjurman och Carl-Henning Wijkmark. Göteborg: Daidalos.

Huldén, Lars 1986. Det paradoxala i Gösta Ågrens lyrik. Ben Hellman \& Clas Zilliacus (red.), Tio finlandssvenska författare. Helsingfors: Skrifter utgivna av Svenska litteratursällskapet i Finland nr 535, 125-147.

Häll, Jan 2006. Vägen till landet som icke är. Essäer om Edith Södergran och Rudolf Steiner. Stockholm: Atlantis, Helsingfors: Skrifter utgivna av Svenska litteratursällskapet i Finland nr 686.

Larsson, Lars-Olof 2016. Karin Månsdotter. Nationalencyklopedin.

http://www.ne.se/uppslagsverk/encyklopedi/lång/karin-månsdotter (2.9.2016).

Lillqvist, Holger 2001. Avgrund och paradis. Studier i den estetiska idealismens litterära tradition med särskild hänsyn till Edith Södergran [diss.]. Helsingfors: Skrifter utgivna av Svenska litteratursällskapet i Finland nr 627.

Madsen, Claus Kruchov 2016. Langdigtsbetegnelsen: en begrebsdiskussion i anledning af modtagelsen af Gösta Ågrens Centralsång (2013). Finsk Tidskrift 2/2016, 7-26.

Möller-Sibelius, Anna 2016. "Slottet av grå verklighet". Idealism och ideologi i Gösta Ågrens efterkrigstida poesi. Historiska och litteraturhistoriska studier 91. Jennica Thylin-Klaus och Martin Welander (red.), Helsingfors: Skrifter utgivna av Svenska litteratursällskapet i Finland nr 807, 67-95.

Steiner, Rudolf 1913. Huru uppnås kunskap om högre världar? I bandet. Översättning från fjärde tyska upplagan av Ellen Backman. Helsingfors: A-B. Helsingfors bokoch stentryckeri.

Steiner, Rudolf 1963. Antroposofin i teori och praktik. Förord av Walter Ljungquist.

Efterskrift av Hans Mändl. Översättning Anna-Lisa Lundkvist. Stockholm: Orion/ Bonniers.

Stenwall, Åsa 2006. Rötter och rotlöshet hos några österbottniska författare. Helsingfors: Schildts.

Willner, Sven 1988. Det anonyma 50-talet. Helsingfors: Söderströms.

Ågren, Gösta 1959. Bergsväg. Helsingfors: Söderströms.

Ågren, Gösta 1963. Säg farväl åt natten. Stockholm: Bonniers.

Ågren, Gösta 1965. Kungörelser. Helsingfors: Söderströms.

Ågren, Gösta 1970. Cellens dagrar. Helsingfors: Söderströms. 
Ågren, Gösta 1970. En annan tanke vid sidan om eller "Det är ett helvete att måla himlar". Vasabladet den 5/9 [Brages Pressarkiv].

Ågren, Gösta 1971. Kärlek som i allting bor. Dan Anderssons liv och diktning 1916-1920 [diss.]. Göteborg: Zindermans förlag.

Ågren, Gösta 1972. Massmöte på jorden. Helsingfors: Söderströms.

Ågren, Gösta 1974. Natten har djup för oss alla. Vasa: Författarnas Andelslag.

Ågren, Gösta 1976. Var inte rädd. Vasa: Skrivor.

Ågren, Gösta 1977. Vår historia. En krönika om det finlandssvenska folkets öden, en analys av vårt lands historia. Vasa: Skrivor.

Ågren, Gösta 1978. Molnsommar. Vasa: Skrivor.

Ågren, Gösta 1979. Paus. Valda dikter 1955-1980, Vasa: Skrivor.

Ågren, Gösta 1990. En dal i våldet. Poesin 1955-1985 i urval. Stockholm: Norstedts.

Ågren, Gösta 2015. Dikter utan land. Helsingfors: Schildts \& Söderströms.

Ågren, Gösta 2016. Samlade dikter 1955-2015. Helsingfors: Schildts \& Söderströms. 